\title{
Short peptide based nanotubes capable of effective curcumin delivery for treating drug resistant malaria
}

\author{
Shadab Alam, Jiban Jyoti Panda², Tapan Kumar Mukherjee ${ }^{3}$ and Virander Singh Chauhan ${ }^{\text {* }}$
}

\begin{abstract}
Background: Curcumin $(\mathrm{Ccm})$ has shown immense potential as an antimalarial agent; however its low solubility and less bioavailability attenuate the in vivo efficacy of this potent compound. In order to increase Ccm's bioavailability, a number of organic/inorganic polymer based nanoparticles have been investigated. However, most of the present day nano based delivery systems pose a conundrum with respect to their complex synthesis procedures, poor in vivo stability and toxicity issues. Peptides due to their high biocompatibility could act as excellent materials for the synthesis of nanoparticulate drug delivery systems. Here, we have investigated dehydrophenylalanine ( $\triangle \mathrm{Phe}$ ) di-peptide based self-assembled nanoparticles for the efficient delivery of $\mathrm{Ccm}$ as an antimalarial agent. The self-assembly and curcumin loading capacity of different $\triangle$ Phe dipeptides, phenylalanine- $a, \beta$-dehydrophenylalanine $(F \Delta F)$, arginine-a, $\beta$ dehydrophenylalanine (R $\triangle F)$, valine- $a, \beta$-dehydrophenylalanine $(V \Delta F)$ and methonine- $a, \beta$-dehydrophenylalanine $(M \triangle F)$ were investigated for achieving enhanced and effective delivery of the compound for potential anti-malarial therapy.

Results: $F \Delta F, R \triangle F, V \triangle F$ and $M \triangle F$ peptides formed different types of nanoparticles like nanotubes and nanovesicles under similar assembling conditions. Out of these, $F \Delta F$ nanotubes showed maximum curcumin loading capacity of almost $68 \%$ W/W. Ccm loaded F $\Delta \mathrm{F}$ nanotubes (Ccm-F $\Delta F)$ showed comparatively higher $\left(\mathrm{IC}_{50}, 3.0 \mu \mathrm{M}\right)$ inhibition of Plasmodium falciparum (Indo strain) as compared to free $\mathrm{C} c \mathrm{~cm}\left(\mathrm{IC}_{50}, 13 \mu \mathrm{M}\right)$. $\mathrm{Ccm}-\mathrm{F} \Delta \mathrm{F}$ nano formulation further demonstrated higher inhibition of parasite growth in malaria infected mice as compared to free $\mathrm{Ccm}$. The dipeptide nanoparticles were highly biocompatible and didn't show any toxic effect on mammalian cell lines and normal blood cells.
\end{abstract}

Conclusion: This work provides a proof of principle of using highly biocompatible short peptide based nanoparticles for entrapment and in vivo delivery of Ccm leading to an enhancement in its efficacy as an antimalarial agent.

Keywords: Nanotubes, Antimalarial, Self-assembly, Peptide, Curcumin

\section{Background}

Malaria, one of the most devastating infectious disease, affects almost half of the global population [1]. In humans, malaria is caused by a unicellular organism, the Plasmodium parasite and is transmitted through the female Anopheles mosquito. Plasmodium parasite has many different species, of which $P$. falciparum accounts for most human deaths mostly in sub Saharan Africa. Malaria symptoms are generally associated with

\footnotetext{
*Correspondence: viranderschauhan@gmail.com; virander@icgeb.res.in ${ }^{1}$ International Centre for Genetic Engineering and Biotechnology, New Delhi 110067, India

Full list of author information is available at the end of the article
}

headache, chills, fever and vomiting, which are initially mild and hence difficult to distinguish as malaria. If appropriate treatment is not administered within $24 \mathrm{~h}, P$. falciparum infection can progress and cause severe anaemia, respiratory distress or cerebral malaria which often leads to death [2].

In the present scenario, few drugs like chloroquine, sulfadoxine-pyrimethamine (SP), artemisinin and its derivatives are the only available effective treatment modalities for malaria. However, drug resistance and toxicity to most of the available drugs like chloroquine and SP poses a serious and growing challenge to treat malaria [3-7] Artemisinin and its combinations with other drugs 
(ACT's) have been successfully used to treat malaria, but recent reports of resistance to artemisinin particularly in many Southeast Asian countries has made the situation grim $[8,9]$. Therefore, there is an urgent need to develop new drugs and new treatment strategies to cure malaria. Several chemical compounds either synthetic or isolated from natural sources are being actively investigated for their antimalarial activity [10-14] and although there seems to be a fairly good number of anti-malarial molecules in pipeline, the situation is far from satisfactory. Curcumin $(\mathrm{Ccm})$ isolated from the rhizomes of curcuma longa (turmeric), has been shown to possess strong antimalarial activity in several studies. It has been shown to disrupt microtubules, inhibit histone acetylation and generate reactive oxygen species to kill the parasite [1517]. However, certain features like poor absorption, rapid metabolism and fast elimination from the body lead to its low bioavailability and limit its therapeutic effects as an anti-malarial agent [18].

Nanoparticles owing to their small size demonstrate special features like protection of drugs from non-specific degradation, increment in drug half-life, prevention of drug resistance, increased bioavailability, site specific delivery of therapeutic compounds and reduced toxicity to other body parts etc [19-21]. A number of organic/ inorganic polymer based nanoparticles have been developed as efficient drug delivery systems and many of these have also been used for the entrapment and delivery of Ccm [22-24]. However, most of these nanoparticles demonstrate low biocompatibility, which prevent their direct applications in human targets [25-29].

Moreover, the complex way of synthesis of these nanoparticles poses hurdles in their large scale synthesis and commercialization. In this context nanoparticles based on biocompatible building blocks offer an attractive alternative and in recent years a number of peptide based nanoparticles have been reported [30-33]. But, on the other hand peptide based systems also have an inherent drawback in that they are susceptible to enzymatic degradation leading to their short half-life in in vivo situations. In this regard short peptide based nanoparticles; particularly those containing unnatural amino acids may offer an attractive alternate solution. In this direction we have used $\alpha, \beta$-dehydroamino acids in designing short peptides which can self-assemble into stable and highly biocompatible nanostructures and as potential biomolecule delivery system [34-36].

Here, we report synthesis and characterization of $\alpha, \beta-$ dehydrophenylalanine containing self-assembling and biocompatible dipeptide nanoparticles (DNPs) and their potential as drug delivery systems for hydrophobic drugs like $\mathrm{Ccm}$. Results of both in vitro and in vivo studies demonstrated enhanced antimalarial activity with DNPs loaded $\mathrm{Ccm}$ in comparison to the free drug. The unique one step synthesis, long term stability of these DNPs and their biocompatibility make them highly effective platforms for further development as efficient carriers for hydrophobic drug like Ccm.

\section{Results and discussion}

\section{Synthesis and characterisation of the DNPs}

Four different dipeptides used in the present study were synthesised using solution phase peptide synthesis methods. The peptides were purified by reverse phase high performance liquid chromatography (RPHPLC) and characterised using mass spectrometry (Table 1).

For initiating self-assembly, the peptides ( $2 \mathrm{mg}$ each in case of $\mathrm{R} \Delta \mathrm{F}, \mathrm{V} \Delta \mathrm{F}$ and $\mathrm{M} \Delta \mathrm{F}$ and $0.5 \mathrm{mg}$ in case of $\mathrm{F} \Delta \mathrm{F}$ ) were first dissolved in $100 \mu \mathrm{l}$ of isopropanol followed by addition of $1 \mathrm{ml}$ of water. The samples were further incubated for 5-6 h at room temperature. Formation and properties of the DNPs were then studied using dynamic light scattering (DLS) and transmission electron microscopy (TEM). From light scattering studies, it was observed that all the four dipeptides could form monodispersed nanostructures with low polydispersity indices. $\mathrm{R} \Delta \mathrm{F}$ formed nanoparticles with hydrodynamic diameter of $304 \pm 20 \mathrm{~nm}$, whereas $M \Delta \mathrm{F}, \mathrm{V} \Delta \mathrm{F}$, and $\mathrm{F} \Delta \mathrm{F}$ formed nanoparticles of hydrodynamic diameter of $200 \pm 15,220 \pm 25$ and $980 \pm 45 \mathrm{~nm}$ respectively (Table 2). It is likely that dipeptides self assembled under these conditions by virtue of nanoprecipitation mechanism, where isopropanol acted as a solvent and water as an anti-solvent [37]. Hydration with water perhaps renders the hydrophobic moieties of the peptides insoluble, triggering the self-assembly process. Assembly could be stabilized by non-covalent interactions like hydrogen bonding, hydrophobic interactions, van der Waals and electrostatic interactions as well as $\pi-\pi$ stacking interactions between the aromatic residues [38, 39]. Head to tail hydrogen bonding and $\pi-\pi$ stacking interactions responsible for stabilizing the assembled nanotubes were observed in crystal structure of F $\Delta \mathrm{F}$ [34]. This is in line with the self-assembly of Phe-Phe, where the dipeptide was first dissolved in an organic solvent like in hexafluoroisopropanol at a concentration of $100 \mathrm{mg} / \mathrm{ml}$ and then

Table 1 Characterization of dipeptides: HPLC retention time and mass of $F \Delta F, R \Delta F, M \Delta F$ and $V \Delta F$ dipeptide

\begin{tabular}{lllll}
\hline S.No. & Nanostructure & $\begin{array}{l}\text { HPLC retention } \\
\text { time (min) }\end{array}$ & $\begin{array}{l}\text { Expected } \\
\text { mass }\end{array}$ & $\begin{array}{l}\text { Observed } \\
\text { mass }\end{array}$ \\
\hline 1 & $R \Delta F$ & 28.0 & 319.39 & 320.181 \\
2 & $M \Delta F$ & 29.5 & 294.407 & 295.118 \\
3 & $V \Delta F$ & 34.5 & 262.341 & 263.342 \\
4 & $F \Delta F$ & 24.0 & 310.38 & 311.140 \\
\hline
\end{tabular}


Table 2 Characterization of DNPs: hydrodynamic diameters and polydispersity indices of dipeptide nanoparticles

\begin{tabular}{llll}
\hline S.No. & Nanostructure & $\begin{array}{l}\text { Hydrodynamic } \\
\text { diameter }(\mathbf{m m})\end{array}$ & $\begin{array}{l}\text { Polydispersity } \\
\text { index (PDI) }\end{array}$ \\
\hline 1 & $R \Delta F$ & $304 \pm 20$ & 0.07 \\
2 & $M \Delta F$ & $200 \pm 15$ & 0.12 \\
3 & $V \Delta F$ & $220 \pm 25$ & 0.22 \\
4 & $F \Delta F$ & $980 \pm 45$ & 0.36 \\
\hline
\end{tabular}

diluted with water to a final concentration of $0.5 \mathrm{mg} / \mathrm{ml}$ to form nanotubes [40].

Transmission electron microscop (TEM) was used to investigate the morphological details of the nanoparticles. It was observed that $\mathrm{R} \Delta \mathrm{F}$ assembled into vesicular structures with mean diameter of $62 \mathrm{~nm} . \mathrm{M} \Delta \mathrm{F}$ and $\mathrm{V} \Delta \mathrm{F}$ also formed vesicular structures with mean diameter of 40 and $55 \mathrm{~nm}$ respectively. However, similar to our earlier studies [41] the dipeptide $\mathrm{F} \Delta \mathrm{F}$ under these conditions self-assembled into tubular structures with mean diameter of $25 \mathrm{~nm}$ and length in microns (Fig. 1a-d). The final properties of the peptide assemblies, including their size, shape are governed by a delicate balance of the intermolecular interactions mentioned above and hence different dipeptides form different types of nanostructures. Earlier studies have also demonstrated similar phenomenon where a slight change in peptide sequence resulted in the formation of nanostructures of varied morphologies and dimensions $[42,43]$.

\section{In vitro cytotoxicity and haemolytic assay}

Nanoparticle based delivery systems offer several advantages like site-specific delivery of entrapped molecules, yet toxicity of nanomaterial towards healthy cells remains an important concern $[19,44]$. In vitro cytotoxicity of void DNPs was assessed in mouse fibroblasts (L929) cultured in RPMI medium. Cells were seeded at a density of $1 \times 10^{4}$ cells per well in $200 \mu \mathrm{l}$ of cell growth medium and exposed to increasing concentrations of DNPs $(0-4000 \mu \mathrm{M})$ for period of $24 \mathrm{~h}$, followed by measurement of cell viability using MTT assay. The $50 \%$ cytotoxicity concentration $\left(\mathrm{CC}_{50}\right)$ of these DNPs were found to be $800,1160,2680$ and $3100 \mu \mathrm{M}$ for $\mathrm{V} \Delta \mathrm{F}, \mathrm{F} \Delta \mathrm{F}, \mathrm{M} \Delta \mathrm{F}$ and $\mathrm{R} \Delta \mathrm{F}$ respectively (Fig. $2 \mathrm{a}$ ).

Cytotoxicity was also assessed with lactate dehydrogenase (LDH) release assay. LDH is a soluble cytosolic enzyme that is released into the culture medium following loss of membrane integrity resulting from either apoptosis or necrosis. LDH activity, therefore, can be used as an indicator of cell membrane integrity and serves as a general mean to assess cytotoxicity resulting from chemical compounds or environmental toxic factors. L929 cells treated with the DNPs at a concentration of $50 \mu \mathrm{M}$, exhibited similar release of LDH to the media as untreated cells, suggesting that these DNPs are safe for in vivo applications (Fig. $2 b$ ).

Nanoformulations delivered into the body, will finally enter the circulation and may adversely affect the red blood cells (RBCs). Hemolysis (destruction of red blood cells) can lead to anemia, jaundice and other pathological conditions; therefore the hemolytic potential of all intravenously administered pharmaceuticals must be evaluated. Measuring the percentage of hemolysis is an appropriate way to detect the toxicity of a test compound towards RBCs $[45,46]$. We performed hemolytic assays for all four DNPs at three different concentrations $(10,20$ and $50 \mu \mathrm{M})$ and found that none of the DNPs were hemolytic even at $50 \mu \mathrm{M}$ concentration (Fig. 2c). Results of cytotoxicity and hemolysis assay suggested that these DNPs are highly biocompatible and therefore safe for biological applications, including intra venous drug delivery.

\section{Loading the DNPs with $\mathrm{Ccm}$}

Dissolution and entrapment of highly hydrophobic drugs like $\mathrm{Ccm}$ inside nano or micro-carriers requires strong nonaqueous solvents and it is generally difficult to remove the solvent from the final drug-nano formulation, which is a concern in their potential application in in vivo drug delivery $[47,48]$. Dipeptide based nanoparticles reported here are prepared under largely aqueous environment endowing them the suitability for potential in vivo applications. After characterizing the DNPs, we next investigated their ability to load $\mathrm{Ccm}$ following the post loading method. Ccm was dissolved in methanol $(10 \mathrm{mg} / \mathrm{ml})$ and DNPs were incubated with three different concentrations of $\mathrm{Ccm}(1,2$ and $3 \mathrm{mg}$ of $\mathrm{Ccm} /$ $\mathrm{ml}$ of DNPs) for $72 \mathrm{~h}$. Unbound Ccm was removed by filtration (50 kDa Amicon ${ }^{\circledR}$ Ultra-0.5) followed by lyophylisation of nanoforumlation. Optimum loading was observed at a Ccm concentration of $3 \mathrm{mg} / \mathrm{ml}$. At this concentration, $\mathrm{Ccm}$ loading was found to be $68 \pm 0.07 \%$ $(\mathrm{w} / \mathrm{w})$ in $\mathrm{F} \Delta \mathrm{F}$ nanotubes, $\sim 8 \%(\mathrm{w} / \mathrm{w})$ for $\mathrm{V} \Delta \mathrm{F}$ nanovesicles, $\sim 12 \%(\mathrm{w} / \mathrm{w})$ for $\mathrm{M} \Delta \mathrm{F}$ nanovesicles and $\sim 14 \%(\mathrm{w} / \mathrm{w})$ for $\mathrm{R} \Delta \mathrm{F}$ nanovesicles (Table 3 ). The relatively higher loading observed in case of $\mathrm{F} \Delta \mathrm{F}$ could be attributed to optimum hydrophobic interactions between the drug molecules and the peptide nanotubes and also possibly to enhanced $\pi-\pi$ interactions between planar aromatic structure of the drug and the two aromatic rings in $\mathrm{F} \Delta \mathrm{F}$. Since F $\Delta \mathrm{F}$ turned out to be most efficient in entrapping $\mathrm{Ccm}$, this combination was taken up for further investigations. Ccm-F $\triangle \mathrm{F}$ analyzed using TEM demonstrated that $\mathrm{Ccm}$ loading did not disturb the overall morphology of the DNPs (Fig. 1e). lyophilised Ccm loaded F $\Delta \mathrm{F}$ nanotubes $(\mathrm{Ccm}-\mathrm{F} \Delta \mathrm{F})$ were resupended in water and this 

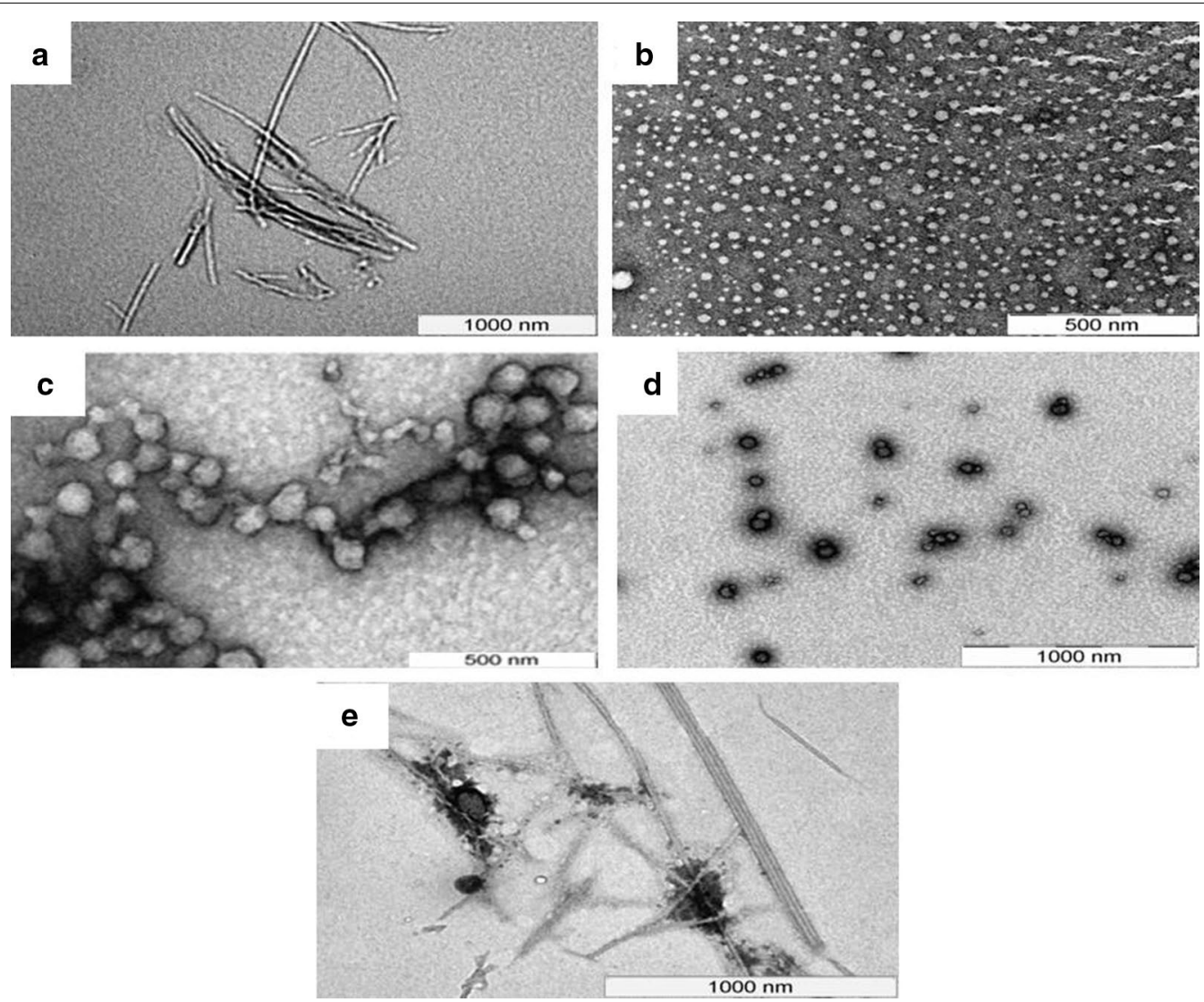

Fig. 1 Transmission electron micrographs of DNPs: TEM image of a F $\triangle F$, showing the formation of tubular structure with mean diameter of $25 \mathrm{~nm}$ and length in microns, $\mathbf{b} M \Delta F$, demonstrating the formation of vesicular structures with mean diameter of $40 \mathrm{~nm} \mathbf{c} V \Delta F$, showing the formation of vesicular structures with mean diameter of $55 \mathrm{~nm}, \mathbf{d}$ R $\Delta F$ demonstrating the formation of vesicular structures with mean diameter of $62 \mathrm{~nm}$ and e $\mathrm{Ccm}-\mathrm{F} \Delta \mathrm{F}$ showing dense tubular structures

suspension in colloidal form was used for drug release, stability as well as for in vitro and in vivo efficacy studies.

\section{Release of $\mathrm{Ccm}$ from $\mathrm{Ccm}-\mathrm{F} \Delta \mathrm{F}$}

$\mathrm{Ccm}$ release from the $\mathrm{Ccm}-\mathrm{F} \Delta \mathrm{F}$ was followed by using dialysis membrane bag method [49, 50]. Release was monitored for a period of $96 \mathrm{~h}$ in a mixture of methanolwater $(1: 1 \mathrm{v} / \mathrm{v})$ as dissolution media. Methanol-water $(1: 1 \mathrm{v} / \mathrm{v})$ was used as a release media because of appropriate solubility of $\mathrm{Ccm}$ in this media which would maintain a sink like condition for the drug release [51]. Release patterns of both free and nanoparticle bound $\mathrm{Ccm}$ are shown in Fig. 3. Free Ccm showed a quicker release (55 $\pm 2.8 \%)$ from the dialysis membrane as compared to $\mathrm{Ccm}-\mathrm{F} \Delta \mathrm{F}(30 \pm 2.5 \%)$ over a period of $6 \mathrm{~h}$. Where almost $90 \%$ of free $\mathrm{Ccm}$ was released from the dialysis membrane in just $9-10 \mathrm{~h}$, the $\mathrm{Ccm}-\mathrm{F} \Delta \mathrm{F}$ nanoformulations took almost $90 \mathrm{~h}$ to release $80 \%$ of the initial loaded $\mathrm{Ccm}$ concentration. Similar release pattern was also observed earlier in case of Ccm loaded in MAX8 peptide hydrogel [52].

\section{Stability of $\mathrm{Ccm}-\mathrm{F} \Delta \mathrm{F}$ nanoparticles}

Use of nanoparticle based systems as possible drug delivery agents necessitates them to be stable over a period of time [53]. We assessed the stability of Ccm-F $\Delta \mathrm{F}$ nanoparticles towards various parameters which include, morphological stability using TEM imaging, retention of drug content and drug release behavior. After being stored for different time periods $(1,7,14,28$ and 56 and 90 days) at room temperature $\left(25 \pm 2{ }^{\circ} \mathrm{C}\right), \mathrm{Ccm}-\mathrm{F} \Delta \mathrm{F}$ were resuspended in water $(1 \mathrm{mg} / \mathrm{ml})$ and observed under TEM. Results demonstrated that the morphology of Ccm-F $\Delta \mathrm{F}$ nanoparticles were intact even after 90 days of storage at room temperature $\left(\left(25 \pm 2{ }^{\circ} \mathrm{C}\right)\right.$ Fig. 4$)$.

Stability of drug content in the nanoparicles was also proved by determining $\mathrm{Ccm}$ stability, content and release from $\mathrm{Ccm}-\mathrm{F} \Delta \mathrm{F}$ over the period of storage. Due to its polyphenolic structure, $\mathrm{Ccm}$ shows inherent fluorescence properties, which also depends on the molecules local environment [54]. Thus, the stability of $\mathrm{Ccm}$ inside the nanoparticles was determined by measuring its fluorescence properties. Fluorescence spectra 

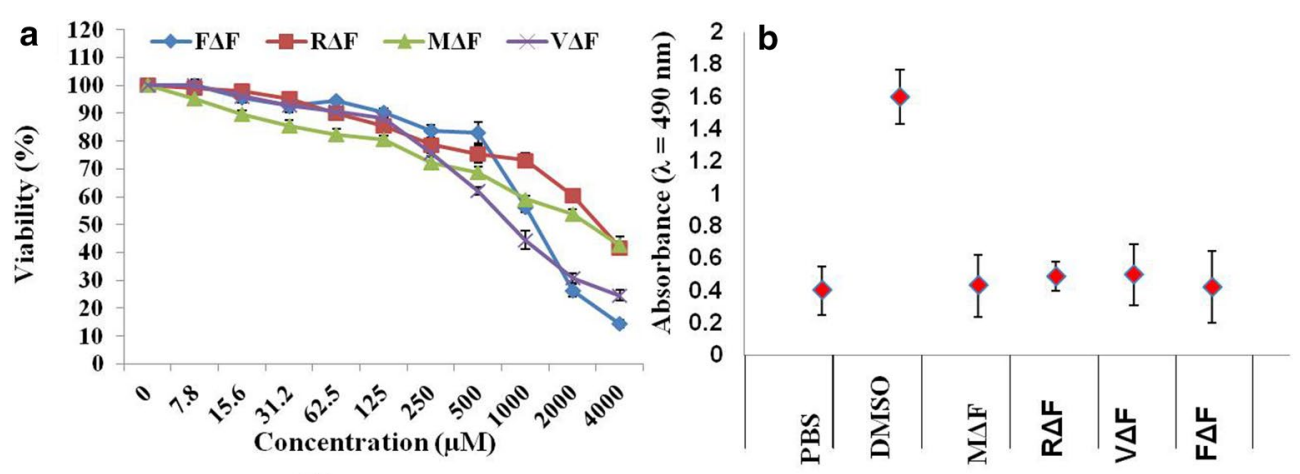

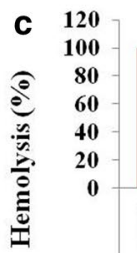

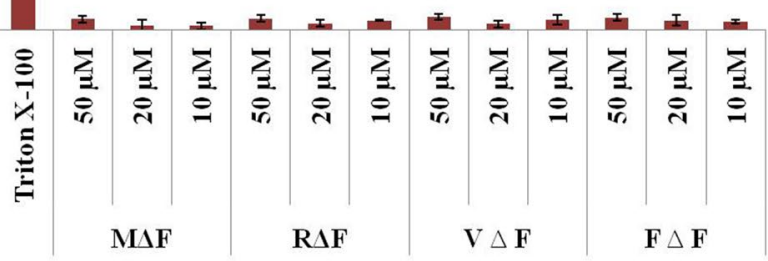

Fig. 2 In vitro cytotoxicity and haemolytic assay: cell toxicity was assessed using a MTT assay. L929 cells were treated with different concentrations i.e., from 0 to $4000 \mu \mathrm{M}$ of the DNPs for $24 \mathrm{~h}$. Viability was expressed as the percentage of media control. $\mathbf{b} \mathrm{LDH}$ release assay: cells treated with $50 \mu \mathrm{M}$ of DNPs showed almost similar release of LDH like PBS treated cells. Cells treated with DMSO as positive control showed the maximum LDH release. c Percentage haemolysis at three different concentrations. None of the DNPs showed haemolytic activity. Triton X-100 taken as a positive control showed $100 \%$ haemolysis

Table 3 Percentage loading of curcumin in DNPs at different concentrations: out of the four DNPs, F $\Delta F$ showed highest loading at a curcumin concentration of $3 \mathrm{mg} / \mathrm{ml}$

\begin{tabular}{llrll}
\hline Curcumin $(\mathbf{m g} / \mathbf{m l})$ & \multicolumn{4}{l}{$\%$ loading } \\
\cline { 2 - 5 } & $\mathbf{F} \boldsymbol{\Delta} \mathbf{F}$ & \multicolumn{1}{l}{$\mathbf{M} \boldsymbol{\Delta} \mathbf{F}$} & $\mathbf{V} \boldsymbol{\Delta} \mathbf{F}$ & \multicolumn{1}{l}{$\mathbf{R} \boldsymbol{\Delta} \mathbf{F}$} \\
\hline 1 & $42 \pm 0.63$ & $8 \pm 0.33$ & $6 \pm 0.68$ & $10 \pm 0.72$ \\
2 & $55 \pm 0.23$ & $10 \pm 0.13$ & $7 \pm 0.55$ & $12 \pm 0.12$ \\
3 & $68 \pm 0.07$ & $12 \pm 0.66$ & $8 \pm 0.35$ & $14 \pm 0.76$ \\
\hline
\end{tabular}

of a methanol: water solution $(1: 1 ; \mathrm{v} / \mathrm{v})$ of $\mathrm{Ccm}$ taken at an excitation wavelength of $425 \mathrm{~nm}$ showed an emission peak at $545 \mathrm{~nm}$. An aqueous methanolic solution of $\mathrm{Ccm}-\mathrm{F} \Delta \mathrm{F}$ at two time points (day 1 and 90) showed a similar emission pattern, suggesting that entrapment in F $\triangle F$ DNPs had no effect on the photophysical properties of $\mathrm{Ccm}$ and also the drug is stable inside the DNPs for a period of 90 days (Fig. 5i). We next estimated the $\mathrm{Ccm}$ content in the DNPs after being stored at the room temperature $\left(25 \pm 2{ }^{\circ} \mathrm{C}\right)$ for a period of 90 days and found that there was no significant change in the $\mathrm{Ccm}$ content of the nanoformulations during these time period (Fig. 5ii). Further, Ccm-F $\Delta \mathrm{F}$ nanoformulations stored at room temperature $\left(25 \pm 2{ }^{\circ} \mathrm{C}\right)$ for 90 days showed release patterns similar to that found on day 1 (Fig. 3). These results taken together demonstrate long term stability of the $\mathrm{Ccm}-\mathrm{F} \Delta \mathrm{F}$ nanoparticles as well as the drug, $\mathrm{Ccm}$, in the DNPs.

\section{In vitro antimalarial activity}

Antimalarial activity of $\mathrm{Ccm}$ has been reported previously $[16,17]$. However, its poor aqueous solubility and hence low bioavailability has limited its use as an antimalarial agent. We have addressed this issue by loading $\mathrm{Ccm}$ in the DNPs and evaluated their activity in parasite culture. Ccm-F $\Delta \mathrm{F}$ showed significant growth inhibition against chloroquine resistant P.falciparum (indo) in comparison with the free drug and nanoparticles alone (Fig. 6). The $\mathrm{IC}_{50}$ value of $\mathrm{Ccm}-\mathrm{F} \Delta \mathrm{F}$ nanoparticles and free $\mathrm{Ccm}$ against $P$. falciparum was found to be 3.0 and $13 \mu \mathrm{M}$ respectively. Thus, the drug loaded nanoparticles demonstrated almost fourfold reduction in the $\mathrm{IC}_{50}$ concentration as compared to native $\mathrm{Ccm}$. Enhancement in anti-malarial activity was also found in case of $\mathrm{Ccm}$ loaded in chitosan nanoparticles [55].

\section{In vivo antimalarial activity of $\mathrm{Ccm}-\mathrm{F} \Delta \mathrm{F}$}

In vivo antimalarial efficacy of $\mathrm{Ccm}-\mathrm{F} \Delta \mathrm{F}$ nanoparticles and free $\mathrm{Ccm}$ in $P$. berghei (ANKA) infected BALB/c 


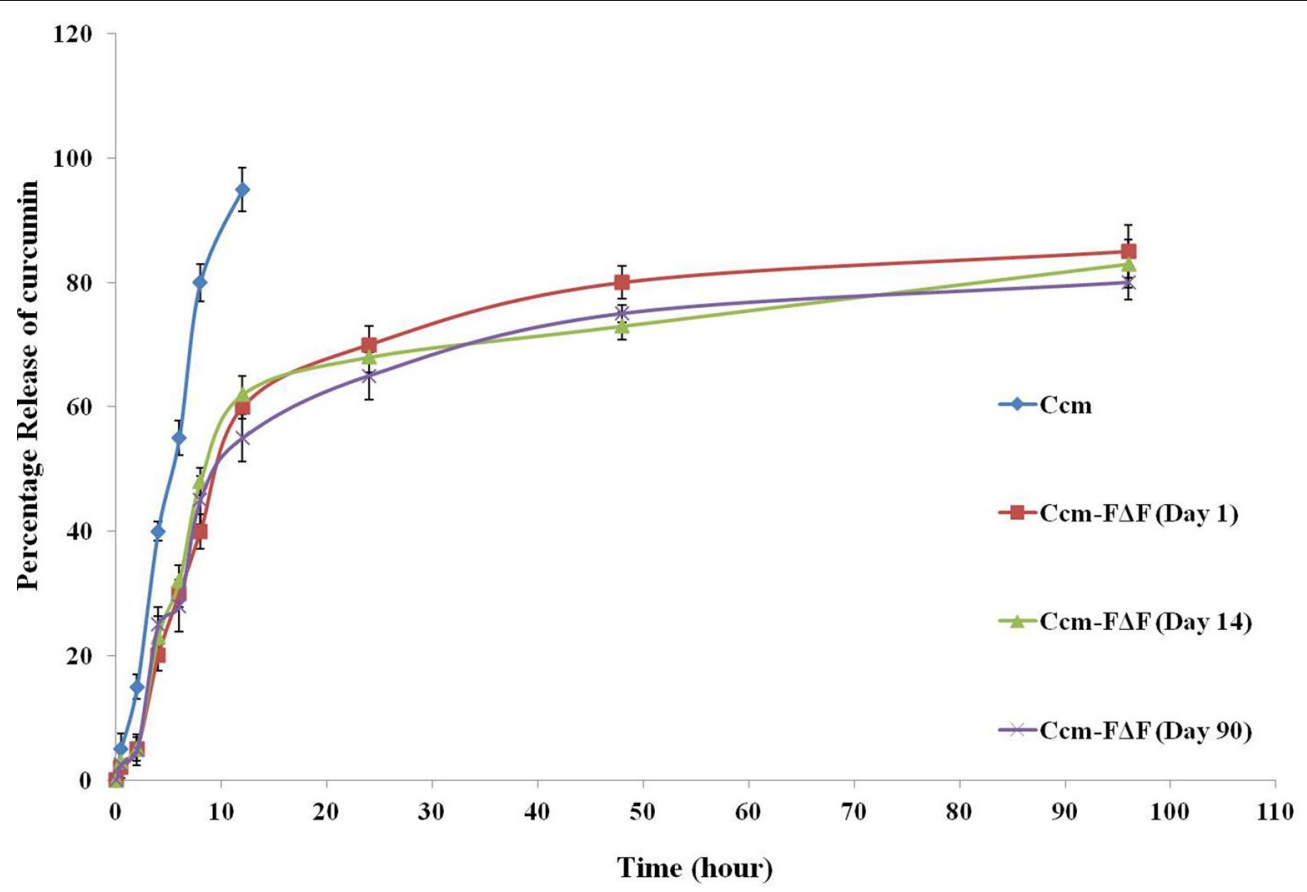

Fig. 3 Release of curcumin from Ccm-F $\Delta F$ : in vitro curcumin release from Ccm-F $\Delta F$ nanoformulations, stored at room temperature for different time points (day 1, 14 and 90) in methanol: water (1:1 v/v). Curcumin content was estimated using (UV-Vis) spectrophotometer at a wavelength of $425 \mathrm{~nm}$. $(\mathrm{n}=3)$, error bar represent \pm standard deviations

mice is presented in Figs. 7 and 8. An analysis of the survival graph of mice and parasite growth count analysis revealed differences between the control groups versus the groups treated with free and entrapped $\mathrm{Ccm}$. In this assay, all mice in the control group treated with PBS, and $\mathrm{F} \Delta \mathrm{F}$, died with high parasitemia between day 10 and 14. In the group of mice treated with $\mathrm{Ccm}$ alone also parasitemia rose at the same rate as the control group, although mice in the group survived somewhat longer than the PBS control group, all mice in this group died by day 18 . In mice treated with $\mathrm{Ccm}-\mathrm{F} \Delta \mathrm{F}$, there was a significant reduction in the growth of parasitemia. Animals administered with $\mathrm{Ccm}-\mathrm{F} \Delta \mathrm{F}$ showed an increased life span and enhanced survival rate as compared to those treated with $\mathrm{Ccm}$ alone. Earlier studies have shown that curcuminoids have beneficial therapeutic effects only in their active form [56, 57]. The attenuated effect of free Ccm might be due to immediate degradation of curcuminoids to inactive metabolic products (trans-6(4-hydroxy-3-methoxyphenyl)-2,4-dioxo-5-hexenal, vanillin, ferulic acid and feruloyl methane) in the blood. The slow release mechanism of $\mathrm{Ccm}$ from the nanoparticles as evident from the in vitro release studies was expected to maintain an effective concentration of $\mathrm{Ccm}$ in the blood as compared to free $\mathrm{Ccm}$ leading to an enhancement in parasite killing efficacy.

\section{Conclusions}

Here, we have described the synthesis and characterisation of $\mathrm{Ccm}$ loaded self-assembled DNPs, which can be easily prepared under relatively mild aqueous conditions. These DNPs are non-cytotoxic and non-haemolytic. Ccm loaded DNPs $(\mathrm{Ccm}-\mathrm{F} \Delta \mathrm{F})$ showed much higher activity of $\mathrm{Ccm}$ in comparison to free $\mathrm{Ccm}$ under both in vitro and in vivo conditions. Such short peptide based delivery systems may have potential for further development for applications in the field of malarial drug delivery.

\section{Methods}

$N$-methyl morpholine (NMM), 1,1,1,3,3,3-hexafluoro2-propanol (HFIP), trifluoroacetic acid (TFA), Ccm (diferuloyl methane), isobutyl chloroformate (IBCF), methanol and DL-threo- $\beta$-Phenylserine was purchased from Sigma-Aldrich (St. Louis, MO, USA). N-[(tertbutoxy)carbonyl]-L-methionine, L-phenylalanine, Anhydrous sodium sulfate and citric acid were obtained from Novabiochem (Merck, Darmstadt, Germany). Diethyl ether, Sodium acetate, tetrahydrofuran (THF), ethyl acetate, and acetonitrile were purchased from Spectrochem Pvt Ltd (Mumbai, India). Cell lines L-929 (Mouse fibroblast) from ATCC (Manassas, VA). Chloroquine resistant strains of $P$. falciparum (Indo) were obtained and grown in human $\mathrm{O}^{+}$erythrocytes at $3 \%$ hematocrit in 

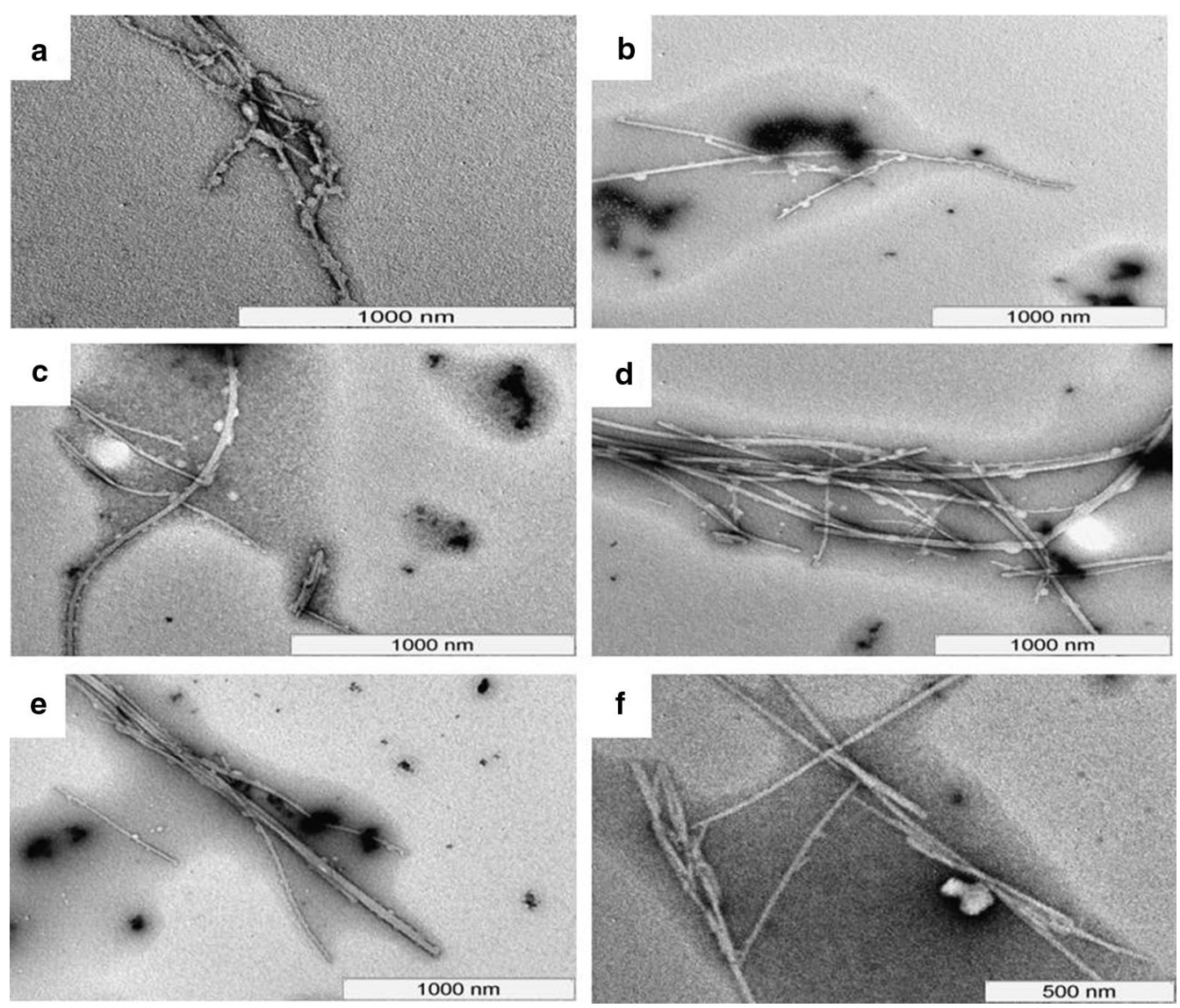

Fig. 4 Stability of $C \mathrm{Cm}-\mathrm{F} \Delta \mathrm{F}$ nanotubes: TEM photographs of curcumin loaded nanotubes at different time points. a-f represent images taken after $1,7,14,28,56$ and 90 days of incubation at room temperature $\left(25 \pm 2^{\circ} \mathrm{C}\right)$. Results demonstrated the stability of curcumin loaded nanotubes over the entire incubation period of 90 days

a complete medium (RPMI 1640 medium supplemented with $25 \mathrm{mM}$ HEPES, pH 7.5, $25 \mathrm{mM}$ sodium bicarbonate, $50 \mathrm{mg} / \mathrm{liter}$ hypoxanthine, $0.5 \%$ Albumax II, and $40 \mu \mathrm{g} / \mathrm{ml}$ gentamicin sulfate). Cultures were maintained at $37^{\circ} \mathrm{C}$ in a gas mixture of $5 \% \mathrm{CO}_{2}$ and $3 \% \mathrm{O}_{2}$. All other chemicals and buffers were of the highest grade available.

\section{Synthesis of nanostructure forming dipeptides}

Synthesis of phenylalanine-dehydrophenylalanine (F $\Delta \mathrm{F})$, was carried out using solution phase peptide synthesis. In brief, Boc-Phe-OH (10 mM; $2.48 \mathrm{~g})$ was dissolved in anhydrous THF, the solution was chilled to $-20{ }^{\circ} \mathrm{C}$ in an ice-salt mixture and kept for stirring for $10 \mathrm{~min}$. IBCF $(10 \mathrm{mM} ; 1.39 \mathrm{ml})$ was then added to the solution followed by NMM $(10 \mathrm{mM} ; 1.31 \mathrm{ml})$. After stirring for $20 \mathrm{~min}$, a pre chilled solution of DL-threo$\beta$-phenylserine (11 mM; $1.98 \mathrm{~g}$ ) and sodium hydroxide (11 mM; $0.44 \mathrm{~g})$ in MQ-water were added. Reaction mixture was stirred over night at room temperature and concentrated in rota evaporator. The residual solution was acidified with chilled concentrated solution of citric acid. Extraction of intermediate product (Boc-Phe-DLthreo- $\beta$-phenylserine) was done by using ethyl acetate. Ethyl acetate solution was then dried by passing through anhydrous sodium sulphate followed by drying in rota vapour. Dried Boc-Phe-DL-threo- $\beta$-phenyl serine were solubilised in acetic anhydride $(100 \mathrm{ml})$ and mixed with sodium acetate $(6.5 \mathrm{mM} ; 1.16 \mathrm{~g})$ and stirred for $36 \mathrm{~h}$. Reaction was stopped by adding crushed ice and filtered the precipitate using grade four filtered funnel. Filtrate was washed thrice with cold water and dried in desiccators. Obtained powder (Boc-Phe- $\Delta$ Phe-azalactone) was dissolved in methanol and stirred with 1.5 equivalent of $1 \mathrm{~N} \mathrm{NaOH}$ for $4 \mathrm{~h}$. Resulting solution was concentrated on rota vapour and extracted with ethyl acetate. Peptide was de protected by treating the compound with anhydrous tetrahydrofuran (THF) and purified on reverse phase HPLC(LC-6 AD, Shimadzu, Kyoto, Japan) using C18 column (Phenomenex, Hyderabad, India, C18, $5 \mu \mathrm{m}$, id $250 \times 4.6 \mathrm{~mm})$ in acetonenitrile $(0.1 \%$ TFA)-water $(0.1 \%$ TFA) with $2 \%$ linear gradient. Other di-peptides used for this study were synthesised using similar method 

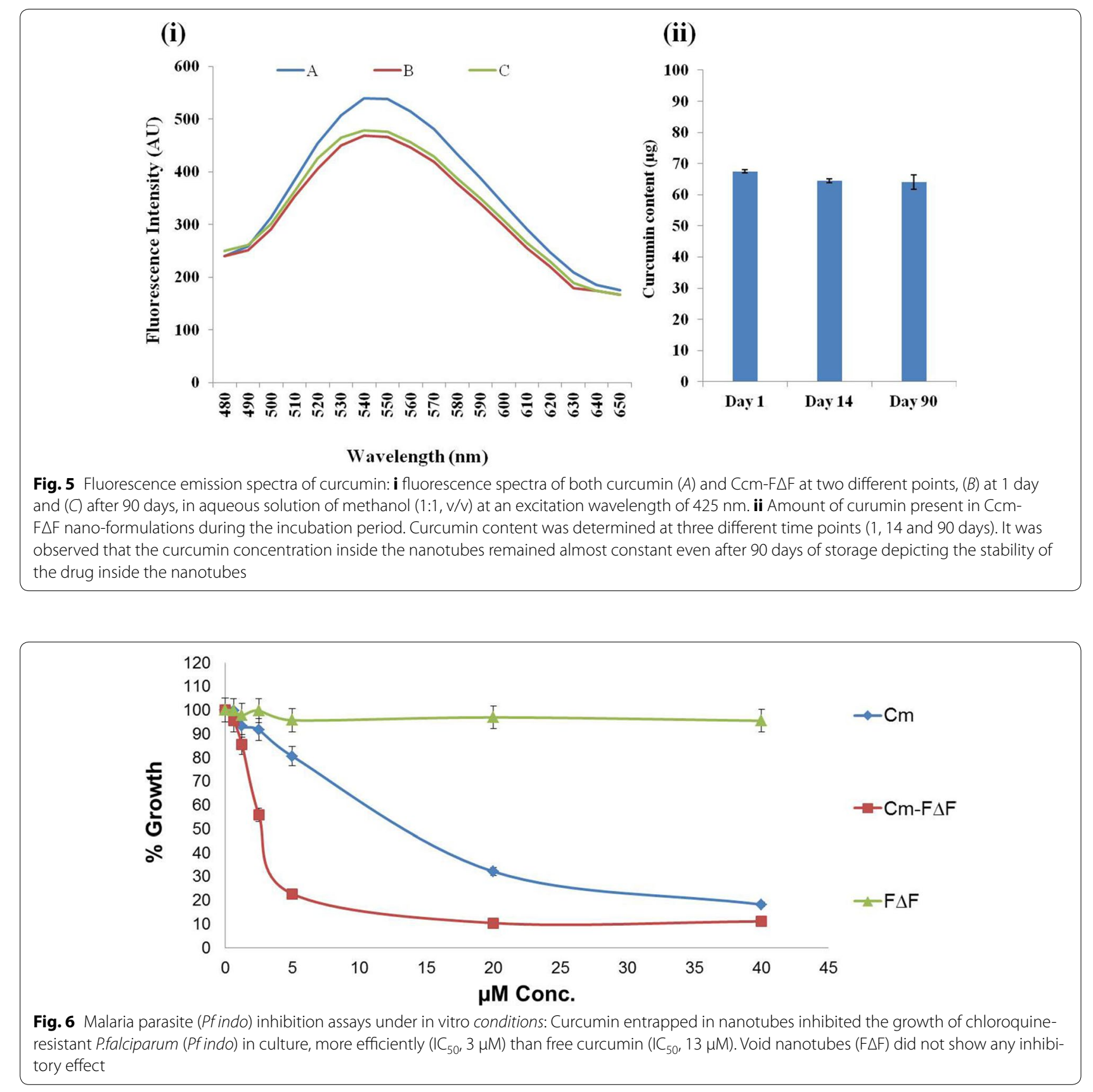

as described above. The mass of peptide were obtained by using mass spectrometer (AppliedBiosystemsQStar (Q-TOF), Ontario, Canada).

\section{Preparation and characterization of DNPs}

Nanostructure of different dipeptides was prepared by dissolving the dipeptides ( $2 \mathrm{mg}$ each in case of $\mathrm{V} \Delta \mathrm{F}$, $\mathrm{M} \Delta \mathrm{F}, \mathrm{R} \Delta \mathrm{F}$ and $0.5 \mathrm{mg}$ in case of $\mathrm{F} \Delta \mathrm{F}$ ) in $100 \mu \mathrm{l}$ of isopropanol. While $\mathrm{M} \Delta \mathrm{F}$ and $\mathrm{R} \Delta \mathrm{F}$ were found to be soluble in isopropanol, $\mathrm{V} \Delta \mathrm{F}$ and $\mathrm{F} \Delta \mathrm{F}$ were only soluble when heated. Self-assembly of these dipeptides was initiated by addition of $1 \mathrm{ml}$ of water to the isopropanol solution of the dipeptides followed by incubation for $4-6 \mathrm{~h}$ at room temperature prior to use.

\section{Dynamic light scattering studies}

DLS was used to determine the particle size and size distribution of these self-assembled nanoparticles. Light scattering studies were performed on Zetasizer NanoZS90 (Malvern Ltd, Malvern, UK) at an angle of $90^{\circ}$ using a $633 \mathrm{~nm}$ laser. All these experiments were performed at room temperature and under dust free environment. 


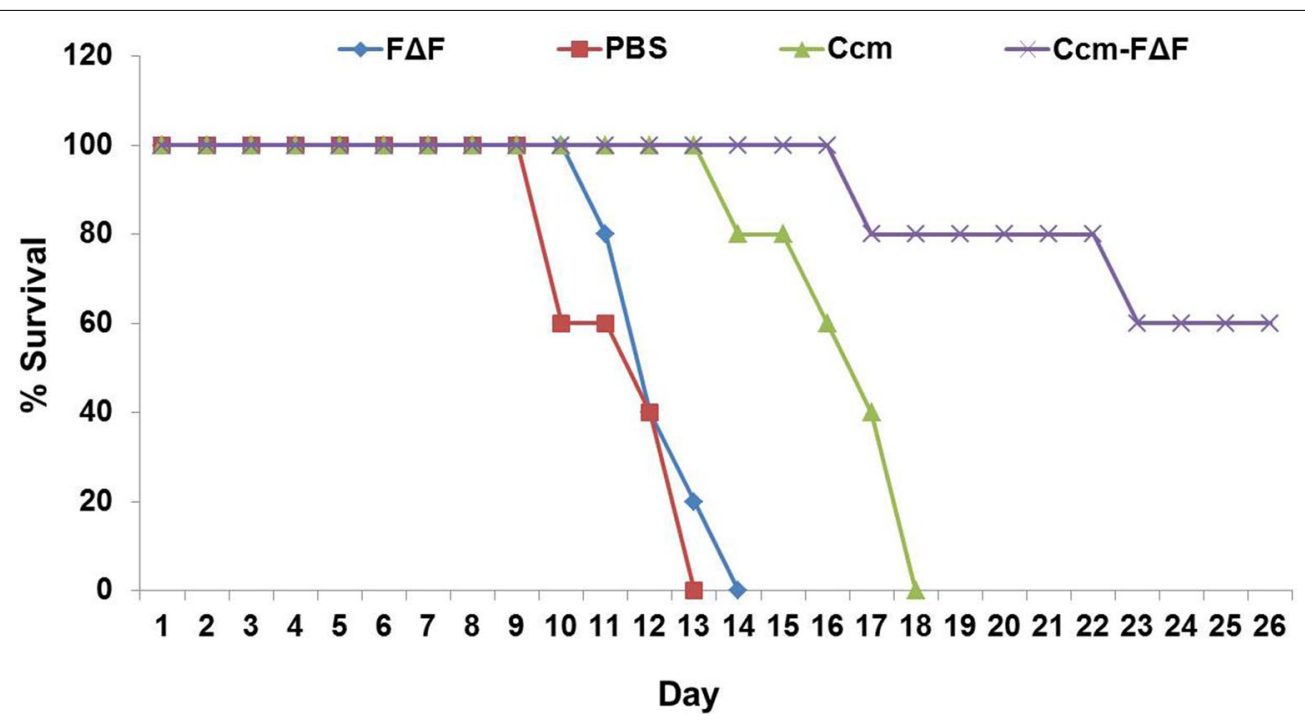

Fig. 7 Survival graph of $P$. bergi-infected mice treated with different groups. Most of the mice in the group treated with PBS and F $\triangle F$ died with high parasitemia between 10 and 14 days of infection. Mice treated with free $\mathrm{Ccm}$ showed increased life span but died earlier than those treated with $\mathrm{Ccm}-\mathrm{F} \Delta \mathrm{F}$

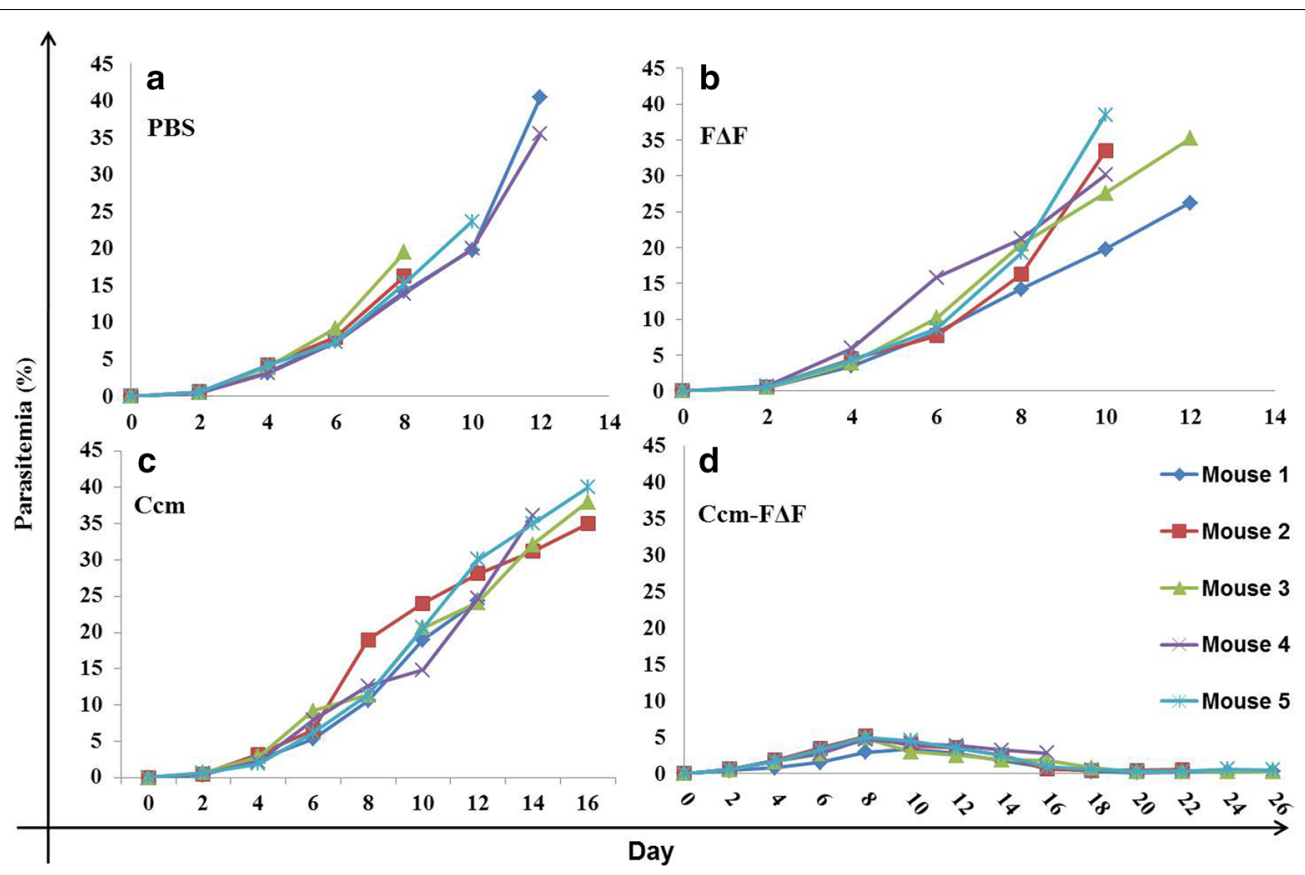

Fig. 8 Percentage parasitemia of different groups of mice: Mice treated with intra-peritoneal injection of the nanoformulations. a PBS and $\mathbf{b} F \triangle F$ treated group. These groups showed increase in parasitemia with time killing all the animals. c Ccm (50 mg/kg BW of curcumin) treated group, where parasitemia rose slowly and mice survived for the longer time as compared to the PBS control group. $\mathbf{d}$ Mice treated with Ccm-F $\triangle F$ (equivalent to $50 \mathrm{mg} / \mathrm{kg}$ BW of curcumin) showed significant decrease in parasitemia and increase in life span

\section{Structural characterization of DNPs using transmission electron microscopy}

Transmission electron microscopy of DNPs was carried out using uranyl acetate negative staining method. In brief, DNPs were loaded by adsorbing a drop of DNPs on a 200 mesh $3 \mathrm{~mm}$ carbon supported nickel grid. Staining of loaded DNPs was done by incubating the loaded grid with $1 \%$ uranyl acetate for $30 \mathrm{~s}$ at room temperature. The 
loaded grid was air dried at room temperature prior to be observed under the microscope. Samples were observed under a transmission electron microscope (TEM) (Tecnai 120 BioTWIN, FEI Netherlands) operated at $120 \mathrm{kV}$. The image was captured using a Megaview II digital camera and analysis was carried out using Analysis II (Megaview, SIS, Germany) the iTem software package.

\section{In vitro cytotoxicity assays \\ Cell viability assay (MTT assay)}

Cytotoxic effect of void DNPs was assessed by the 3-(4,5-dimethylthiazole-2-yl)-2,5-diphenyltetrazolium bromide (MTT) dye conversion assay. MTT is a yellow tetrazole that gets converted into a purple insoluble formazan because of the mitochondrial reductase enzyme present in live cells. The Mouse fibroblast cell line (L929) was purchased from ATCC and maintained in Roswell Park Memorial Institute (RPMI) cell growth medium supplemented with $10 \%$ heat inactivated fetal bovine serum (HI-FBS) at $37{ }^{\circ} \mathrm{C}$ in a $5 \% \mathrm{CO}_{2}$ incubator. Following two passages, the cells were harvested and seeded at a density of $1 \times 10^{4}$ cells/well in $200-\mu \mathrm{l}$ of complete cell culture growth medium, in a 96-well cell culture plate. After $12 \mathrm{~h}$ of incubation, the cultured cells were treated with different concentrations $(0-4000 \mu \mathrm{M})$ of DNPs and incubated in the same incubator for another $24 \mathrm{~h}$. Media was then replaced with fresh media after $24 \mathrm{~h}$ and cells were treated with $20 \mu \mathrm{l}(5.0 \mathrm{mg} / \mathrm{ml}$ in PBS) of MTT (filter sterilised using $0.2 \mu$ filter) for $4 \mathrm{~h}$. Once the incubation period was over, media from each well was removed and $100 \mu \mathrm{l}$ of DMSO was added into each well to dissolve purple formazan which is formed in live cells. The absorbance of formazan was measured at $570 \mathrm{~nm}$ using a microplate reader (VERSAmax Tunable Microplate Reader; Molecular Devices, CA, USA). The cell viability was expressed as the percentage of control using the following equation:

$$
\text { Percentage }(\%) \text { viability of cells }=\frac{\operatorname{Abs}(T)}{\operatorname{Abs}(C)} \times 100
$$

where "Abs (T)" is the absorbance of cells treated with DNPs and "Abs $(C)$ " is the absorbance of the untreated cells.

\section{Lactate dehydrogenase (LDH) leakage assay}

Lactate dehydrogenase is a cytosolic enzyme present in live cells. In case of any damage to plasma membrane $\mathrm{LDH}$ is extruded into the media. Quantitative measurement of LDH leakage provides an estimate of the cellular cytotoxicity caused due to loss of membrane integrity. $\mathrm{LDH}$ activity in the supernatant of the culture medium was determined using a commercial LDH based in vitro toxicology assay test (TOX-7, sigma). In short, $1 \times 10^{4}$ cells were seeded into each well of a 96-well cell culture plate containing $200 \mu \mathrm{l}$ of complete growth medium. After $12 \mathrm{~h}$ of incubation at $37^{\circ} \mathrm{C}$ temperature in $5 \% \mathrm{CO}_{2}$, cells were treated with threefold higher concentration i.e. $50 \mu \mathrm{M}$ of different DNPs and with DMSO as positive control. After $24 \mathrm{~h}$ treatment period, the culture plate was centrifuged in a swing bucket rotor at $250 \mathrm{~g}$ for $5 \mathrm{~min}$ at $37^{\circ} \mathrm{C}$. Fifty micro-liters of supernatant was taken in a 96 well plate and mixed with equal volume of LDH mixture and incubated at room temperature for $30 \mathrm{~min}$. Quantification of the $\mathrm{LDH}$ release into the media was performed by measuring the absorbance at $490 \mathrm{~nm}$.

\section{Haemolysis assay}

Haemolysis assays were performed in heparinised whole blood $(2.5 \mathrm{ml})$ obtained from a healthy male human volunteer. The blood sample was centrifuged at $1000 \times g$ for $20 \mathrm{~min}$ at $37^{\circ} \mathrm{C}$, buffy coat (white blood cells) was removed and the packed cells were washed twice with sterile PBS. PBS was added to the RBCs to obtain $2 \%$ haematocrit. One-hundred micro-liters of cell suspension was added to each well of a 96 well plate containing different concentrations of the DNPs. Negative control included $50 \mu \mathrm{l}$ of PBS solutions added to $100 \mu \mathrm{l}$ of cell suspension (as red blood cell do not lyse in isotonic condition) and $50 \mu \mathrm{l}$ of $1 \%$ Triton X-100 was added in another well as the positive control (as RBCs lyse in a hypotonic medium). Void DNPs of three different concentrations $(10,20$ and $50 \mu \mathrm{M})$ were added to $100 \mu \mathrm{l}$ of cell suspension. Samples were incubated at $37{ }^{\circ} \mathrm{C}$ for $60 \mathrm{~min}$. The reaction was stopped by addition of $50 \mu \mathrm{l}$ of $2.5 \%$ glutaraldehyde. Blood samples were then centrifuged at $1000 \times g$ for $15 \mathrm{~min}$ at $37{ }^{\circ} \mathrm{C}$ and the absorbance of the supernatant was measured at $540 \mathrm{~nm}$ using UVVis spectrometer. The percentage haemolysis was calculated using the following equation:

$$
\text { Hemolysis }(\%)=\frac{\text { Absorbance of Ts }}{\text { Absorbance of Pc }} \times 100
$$

where "Ts" is the absorbance of RBC treated with different concentrations of DNPs and PBS. Whereas "Pc" is the absorbance of RBC treated with $1 \%$ Triton X-100.

\section{Loading of $\mathrm{Ccm}$ in DNPs}

Loading is the most important benchmark for measuring the nanoparticle efficacy as a drug delivery vehicle. Following the formation of nanoparticles (as discussed above), Ccm was loaded on to the DNPs by following post loading method. Briefly, $\mathrm{Ccm}$ was added to the DNPs from a stock solution of the drug $(10 \mathrm{mg} / \mathrm{ml}$ in methanol), at three different concentrations i.e. 1, 2 and $3 \mathrm{mg} / \mathrm{ml}$ of the DNPs and incubated at room temperature for $72 \mathrm{~h}$ with gentle shaking. These nanoparticle 
drug formulations were further processed by ultrasonication for three minutes using sonication probe to remove any large aggregates formed. The nanoparticle dispersions were washed twice with filtered deionized water by centrifuging at $600 \times g$ for $30 \mathrm{~min}$ at room temperature, shock-frozen in liquid nitrogen and lyophilised at $0.40 \mathrm{~m}$ bar and $-80{ }^{\circ} \mathrm{C}$ for $24 \mathrm{~h}$ using freeze dryer. The lyophilised powder was then resuspended in $1 \mathrm{mg} / \mathrm{ml}$ filtered deionized water and characterised using DLS and TEM. To determine the percentage loading capacity (LC) of $\mathrm{Ccm}$ in the DNPs, we employed methods described in previous studies [36]. In brief, lyophilized Ccm-loaded DNPs were dissolved in $1 \mathrm{ml}$ of methanol. The samples were then centrifuged at $3300 \mathrm{~g}$ for $30 \mathrm{~min}$ at room temperature. The amount of $\mathrm{Ccm}$ in the supernatant was determined at $425 \mathrm{~nm}$ using $\mathrm{V}$-Vis spectrophotometer. Calibration curve was generated using the reference standard and the loading capacity was determined as follows.

$\%$ Loading of curcumin $=\left(\mathbf{W}_{\mathbf{n p}} / \mathbf{W}_{\mathbf{a d}}+\mathbf{W}_{\mathrm{dp}}\right) \times \mathbf{1 0 0}$

where $W_{n p}$ refers to the total weight of $\mathrm{Ccm}$ in the nanoparticles; $\mathrm{W}_{\mathrm{ad}}$ the weight of $\mathrm{Ccm}$ added to the nanoparticles and $\mathrm{W}_{\mathrm{dp}}$ the total dipeptide weight in the formulation.

\section{In vitro $\mathrm{Ccm}$ release}

An In vitro release study of $\mathrm{Ccm}$ was performed to monitor the $\mathrm{Ccm}$ release profile at different time points using dialysis bags (MWCO: 3000) with floater (Spectrum Laboratories, CA, USA). Briefly, lyophilised Ccm-F $\Delta \mathrm{F}$ nanoparticles (Stored for different time points day1, 14 and 90) equivalent to $1 \mathrm{mg}$ of $\mathrm{Ccm}$, was dispersed in $1 \mathrm{X}$ PBS and filled in a dialysis bag, stirred at $100 \mathrm{rpm}$ at $37{ }^{\circ} \mathrm{C}$, under sink condition in $250 \mathrm{ml}$ of 1:1 methanol: water, due to higher solubility of $\mathrm{Ccm}$ in this solvent mixture. At different time points $(0.5,1,2,4,6,12,24,48$, and $96 \mathrm{~h})$ $1 \mathrm{ml}$ of receptor medium was removed and replaced with same volume of fresh medium to maintain the total volume of release medium. To estimate $\mathrm{Ccm}$ release, $1 \mathrm{ml}$ of receptor medium was lyophilised, resuspended in methanol and quantified using (UV-Vis) spectrophotometer at a wavelength of $425 \mathrm{~nm}$.

\section{Long term stability of $\mathrm{Ccm}$ loaded $\mathrm{F} \Delta \mathrm{F}(\mathrm{Ccm}-\mathrm{F} \Delta \mathrm{F})$}

Long term stability of $\mathrm{Ccm}-\mathrm{F} \Delta \mathrm{F}$ was analyzed by a FEI Tecnai TEM at $120 \mathrm{kV}$ (FEI Europe, The Netherlands) at different $(1,7$ th, 14th, 28th and 56th and 90th day) time points after negative staining with uranyl acetate $(1 \%$ in MQ water). Nanoformulations were prepared and lyophilised as described above, resuspended in PBS and stored at room temperature, to evaluate the long term stability. On completion of different time points $(1,7$ th, 14th, 28th and 56th and 90th day) Ccm-F $\Delta \mathrm{F}$ were adsorbed on 200 mesh $3 \mathrm{~mm}$ carbon supported nickel grids and stained for $30 \mathrm{~s}$ with $1 \%$ uranyl acetate and viewed under the electron microscope. Photomicrographs were digitally recorded using a Megaview II (SIS, Germany) digital camera. Image analysis to measure tube dimensions was carried out using Analysis II (Megaview, SIS, Germany) software package.

\section{Photophysical properties of $\mathrm{Ccm}$ and $\mathrm{Ccm}$ content in $\mathrm{Ccm}-\mathrm{F} \Delta \mathrm{F}$}

To determine whether entrapment in DNPs had any effect on Ccm's photophysical properties after a long term storage of 90 days at room temperature $\left(25 \pm 2{ }^{\circ} \mathrm{C}\right)$, fluorescence spectra of $\mathrm{Ccm}-\mathrm{F} \Delta \mathrm{F}$ were taken at different time points (day 1 and 90) and compared with that of free $\mathrm{Ccm}$. Fluorescence spectra of both native $\mathrm{Ccm}$ and $\mathrm{Ccm}$ $\mathrm{F} \Delta \mathrm{F}$ at a concentration of $1 \mathrm{mg} / \mathrm{ml}$ were measured in an aqueous solution of methanol ( $1: 1 \mathrm{v} / \mathrm{v}$, methanol: water). Fluorescence emission spectra were recorded from 480 to $650 \mathrm{~nm}$ with an excitation wavelength of $425 \mathrm{~nm}$ (LS 55; Perkin Elmer). To determine the stability of Ccm in the nanoparticles without any leakage, total $\mathrm{Ccm}$ content in the DNPs was checked at different time points (day 1 , 14 and 90). This was carried out by dissolving $100 \mu \mathrm{g}$ of $\mathrm{Ccm}-\mathrm{F} \Delta \mathrm{F}$ in $500 \mu \mathrm{l}$ of methanol and then recording the absorption spectra at $425 \mathrm{~nm}$ using a microplate reader (VERSA max Tunable Microplate Reader; Molecular Devices, CA, USA). Ccm content was determined by comparing the sample with $\mathrm{Ccm}$ standard curve in methanol.

\section{In vitro anti-malarial activity of $\mathrm{Ccm}-\mathrm{F} \Delta \mathrm{F}$}

Chloroquine resistant $P$. falciparum INDO strain was used for growth inhibition assays. Parasites were grown under in vitro conditions by the method of Trager and Jensen with minor modifications [58]. In short, parasite cultures were maintained in fresh $\mathrm{O}^{+}$human erythrocytes with $4 \%$ hematocrit in complete RPMI1640 medium (RPMI 1640 with $0.2 \%$ sodium bicarbonate, $0.5 \%$ Albumax, $45 \mathrm{mg} / \mathrm{l}$, hypoxanthine and $50 \mathrm{mg} / \mathrm{l} \mathrm{gen-}$ tamicin) at $37{ }^{\circ} \mathrm{C}$ under reduced $\mathrm{O}_{2}$ (gas mixture of $5 \%$ $\mathrm{O}_{2}, 5 \% \mathrm{CO}_{2}$, and $90 \% \mathrm{~N}_{2}$ ). Ccm, curcumin loaded $\mathrm{F} \Delta \mathrm{F}$ $(\mathrm{Ccm}-\mathrm{F} \Delta \mathrm{F})$ and $\mathrm{F} \Delta \mathrm{F}$ stocks were prepared in filtered sterile water. The stocks were diluted to get final assay concentrations (0-40 $\mu \mathrm{M} / 100 \mu \mathrm{l}$ of complete media) and transferred to sterile 96-well flat-bottom tissue culture grade plates. Plasmodium cultures were synchronized at ring stage by $5 \%$ sorbitol solution. Synchronized culture was transferred to drug containing 96-well plates at $2 \%$ hematocrit and $1 \%$ parasitemia. Plasmodium growth inhibition was measured by carrying out high throughput fluorescence based SYBR Green I assay. After $48 \mathrm{~h}$ of 


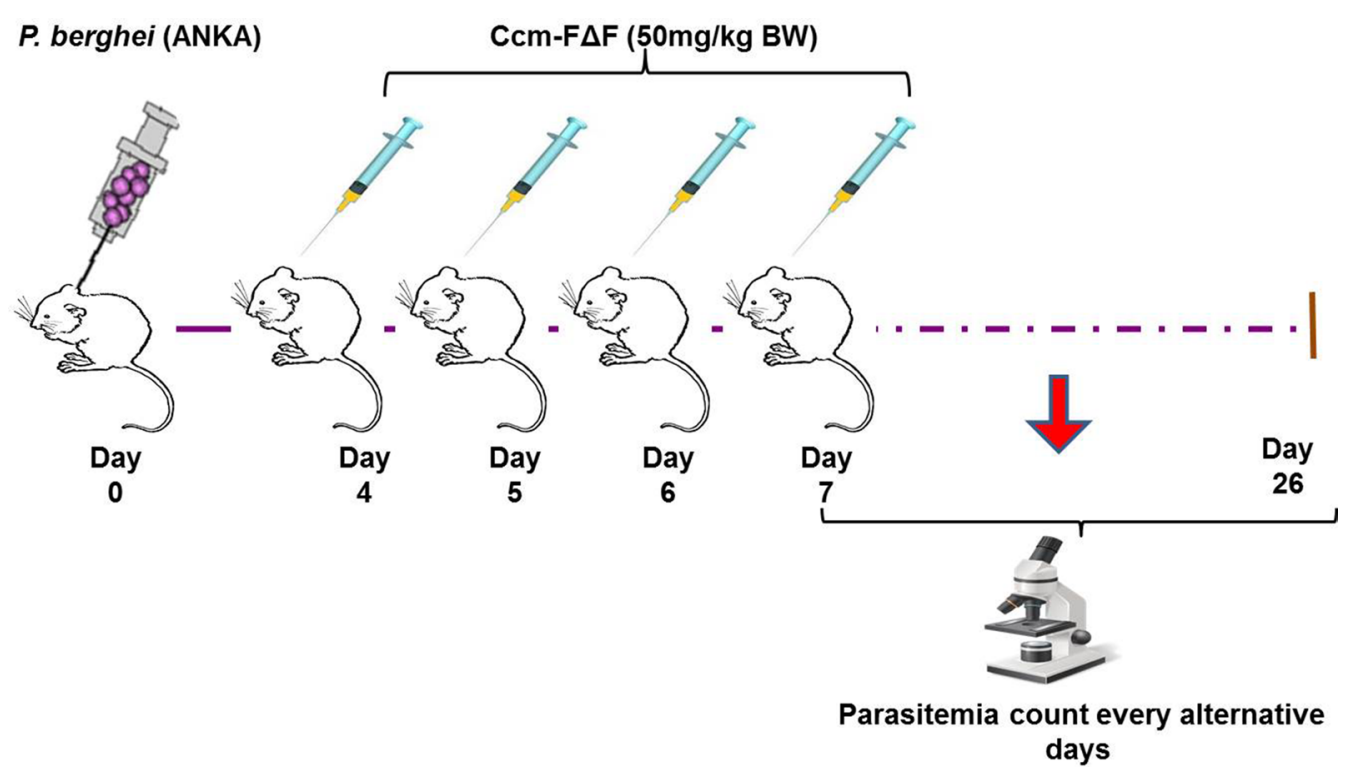

Fig. 9 In vivo antimalarial assay design. After infection with P. berghei (ANKA) mice were treated with different formulations in the corresponding group and parasitemia count was determined every alternative day

incubation the fluorescence of the samples were determined using a 96-well fluorescence plate reader (Victor, Perkin Elmer), with excitation and emission wavelengths at 485 and $530 \mathrm{~nm}$, respectively. The fluorescence readings were plotted against drug concentration and $\mathrm{IC}_{50}$ values were calculated.

\section{Determination of in vivo efficacy Malarial parasites}

The rodent malarial parasite, $P$. berghei ANKA strain was maintained in BALB/c mice by weekly passage of infected blood containing $1 \times 10^{5}$ parasites intraperitonially (i.p.).

\section{Animal model}

Male mice (BALB/c), 4-6 weeks old, weighing 18-20 g were housed in the animal maintenance facility of International Centre of Genetic Engineering and Biotechnology, New Delhi, India. Animal experiments were approved by the Institutional Animal Care and Use Committee and animals were housed for a week for acclimatization in groups of five in the animal house. The animals were fed on commercial pellet diet and water ad libitum in glass bottles. They were maintained under standard conditions of humidity (55-60\%), temperature $\left(22 \pm 3{ }^{\circ} \mathrm{C}\right)$ and light (12:12 h light/dark cycles). Animals used in this study were healthy and did not show any pathological symptoms.

\section{In vivo anti-malarial activity}

Malaria was induced in BALB/c mice (with 18-20 g body weight) through blood transfusion. ANKA strain of P.bergi red blood cells ( $\mathrm{pRBC}$ ) were taken from an infected donor BALB/c mouse (10\% parasitimia) and diluted in PBS to $5 \times 10^{7} \mathrm{pRBC} / \mathrm{ml}$. Mice were infected intraperitoneal with an aliquot of $0.2 \mathrm{ml}$ of this suspension. Mice were then randomly divided into four groups with five mice in each group. Group I: $P$. berghei infection with PBS treatment; Group II: P. berghei infection and F $\Delta \mathrm{F}$ treatment; Group III: P. berghei infection and treatment with $\mathrm{Ccm}-\mathrm{F} \Delta \mathrm{F}$ (actual $\mathrm{Ccm}$ content was $50 \mathrm{mg} / \mathrm{kg}$ body weight); Group IV: P. berghei infection and Ccm treatment (50 $\mathrm{mg} / \mathrm{kg}$ body weight). After reaching paracitemia 1-2\%, mice were treated for four successive days by intraperitoneal injection. Blood smears were prepared every alternate day from the tail vein for the period of 26 days (Fig. 9). Animals were kept under daily supervision for clinical signs and weight loss.

\section{Measurement of parasitemia}

Measurement of parasitemia was carried out after giemsa staining of parasites followed by microscopic imaging under oil immersion objective at $100 \times$ magnification. The percentage of infected erythrocytes was calculated in the fields of 1000 erythrocytes.

\section{Abbreviations}

$F \Delta F$ : phenylalanine- $a, \beta$-dehydrophenylalanine; $R \triangle F$ : arginine- $a, \beta$ dehydrophenylalanine; $V \Delta \mathrm{F}$ : valine-a, $\beta$-dehydrophenylalanine; $M \triangle F$ : methonine-a, $\beta$-dehydrophenylalanine; $C \mathrm{~cm}-\mathrm{F} \Delta \mathrm{F}$ : curcumin loaded $\mathrm{F} \Delta \mathrm{F}$ nanotubes; DLS: dynamic light scattering; TEM: transmission electron microscope; PLGA: poly (lactic-co-glycolic acid); DNPs: dipeptide nanoparticles; MWCO: 
molecular weight cut-off; $I C_{50}$ : inhibitory concentration; IP: intra peritoneal; Ccm: curcumin; kV: kilo volt.

\section{Authors' contributions}

SA carried out all the experiments and drafted the manuscript. JJP helped in TEM imaging and designing of experiments and drafting of the manuscript. TKM participated in the experiment design. VSC was involved in all studies and experiment designs and finalization of the manuscript. All authors read and approved the final manuscript.

\section{Author details}

${ }^{1}$ International Centre for Genetic Engineering and Biotechnology, New Delhi 110067, India. ${ }^{2}$ Institute of Nano Science and Technology, Mohali, Punjab 160062, India. ${ }^{3}$ Maharishi Markandeshwar University, Ambala, Haryana 133207, India.

\section{Acknowledgements}

SA thanks Indian Council of Medical Research, India, for providing scholarship. Authors acknowledge the core funding at the International Centre for Genetic Engineering and Biotechnology, New Delhi, and Department of Biotechnology, India, for financial assistance. Authors thank Mr. Dinesh Mohanakrishnan from malaria Group, ICGEB, for his help in the growth and maintenance of the Plasmodium falciparum culture.

\section{Competing interests}

The authors declare that they have no competing interests.

Received: 8 October 2015 Accepted: 23 March 2016

Published online: 05 April 2016

\section{References}

1. Report WM. Malaria media center. In: Organization WH, editor. Geneva: $\mathrm{WHO} ; 2014$.

2. Guinovart C, Navia MM, Tanner M, Alonso PL. Malaria: burden of disease. Curr Mol Med. 2006;6(2):137-40.

3. Bonington A, Davidson RN, Winstanley PA, Pasvol G. Fatal quinine cardiotoxicity in the treatment of falciparum malaria. Trans R Soc Trop Med Hyg. 1996;90(3):305-7.

4. Dondorp AM, Nosten F, Yi P, Das D, Phyo AP, Tarning J, et al. Artemisinin resistance in Plasmodium falciparum malaria. N Engl J Med. 2009;361(5):455-67. doi:10.1056/NEJMoa0808859.

5. Lehane AM, Kirk K. Efflux of a range of antimalarial drugs and 'chloroquine resistance reversers' from the digestive vacuole in malaria parasites with mutant PfCRT. Mol Microbiol. 2010;77(4):1039-51. doi:10.1111/j.1365-2958.2010.07272.x.

6. Afonso A, Hunt P, Cheesman S, Alves AC, Cunha CV, do Rosario V, et al. Malaria parasites can develop stable resistance to artemisinin but lack mutations in candidate genes atp6 (encoding the sarcoplasmic and endoplasmic reticulum Ca2 + ATPase), tctp, mdr1, and cg10. Antimicrob Agents Chemother. 2006;50(2):480-9. doi:10.1128/AAC.50.2.480-489.2006.

7. Aviado DM, Bellet S. Comparative toxicity of chloroquine and bis[(chloro7"-quinolyl-4")-amino-2'propyl]-1,4-piperazine (WR 3863). Toxicol Appl Pharmacol. 1969;15(2):331-44.

8. Miotto O, Almagro-Garcia J, Manske M, Macinnis B, Campino S, Rockett $\mathrm{KA}$, et al. Multiple populations of artemisinin-resistant Plasmodium falciparum in Cambodia. Nat Genet. 2013;45(6):648-55. doi:10.1038/ng.2624.

9. Noedl H, Se Y, Schaecher K, Smith BL, Socheat D, Fukuda MM, et al. Evidence of artemisinin-resistant malaria in western Cambodia. N Engl J Med. 2008;359(24):2619-20. doi:10.1056/NEJMc0805011.

10. Asnake S, Teklehaymanot T, Hymete A, Erko B, Giday M. Evaluation of the antiplasmodial properties of selected plants in southern Ethiopia. BMC Complement Altern Med. 2015;15(1):448. doi:10.1186/s12906-015-0976-x.

11. Nair $L$, Bhasin VK. Cure with cisplatin (II) or murine malaria infection and in vitro inhibition of a chloroquine-resistant Plasmodium falciparum isolate. Jpn J Med Sci Biol. 1994;47(5-6):241-52.

12. Ojurongbe O, Ojo JA, Adefokun DI, Abiodun OO, Odewale G, Awe EO. In vivo antimalarial activities of Russelia Equisetiformis in Plasmodium Berghei infected mice. Indian J Pharm Sci. 2015;77(4):504-10.
13. Parthiban A, Muthukumaran J, Manhas A, Srivastava K, Krishna R, Rao HS Synthesis, in vitro and in silico antimalarial activity of 7-chloroquinoline and 4H-chromene conjugates. Bioorg Med Chem Lett. 2015;25(20):465763. doi:10.1016/j.bmcl.2015.08.030.

14. Verbeeck S, Yadav AK, Maes BU, Augustyns K, Van Der Veken P, Cos P, et al. Antiprotozoal activity of synthetic amino substituted 1-methyl-1 $\mathrm{H}$-alphacarbolines. Pharmazie. 2014;69(2):83-5.

15. Chakrabarti R, Rawat PS, Cooke BM, Coppel RL, Patankar S. Cellular effects of curcumin on Plasmodium falciparum include disruption of microtubules. PLoS One. 2013;8(3):e57302. doi:10.1371/journal.pone.0057302.

16. Cui L, Miao J, Cui L. Cytotoxic effect of curcumin on malaria parasite Plasmodium falciparum: inhibition of histone acetylation and generation of reactive oxygen species. Antimicrob Agents Chemother. 2007;51(2):48894. doi:10.1128/AAC.01238-06.

17. Reddy RC, Vatsala PG, Keshamouni VG, Padmanaban G, Rangarajan PN. Curcumin for malaria therapy. Biochem Biophys Res Commun. 2005;326(2):472-4. doi:10.1016/j.bbrc.2004.11.051.

18. Anand P, Kunnumakkara AB, Newman RA, Aggarwal BB. Bioavailability of curcumin: problems and promises. Mol Pharm. 2007;4(6):807-18. doi:10.1021/mp700113r.

19. Farokhzad OC, Langer R. Nanomedicine: developing smarter therapeutic and diagnostic modalities. Adv Drug Deliv Rev. 2006;58(14):1456-9. doi:10.1016/j.addr.2006.09.011.

20. Shaffer C. Nanomedicine transforms drug delivery. Drug Discov Today 2005;10(23-24):1581-2. doi:10.1016/S1359-6446(05)03654-8.

21. Zhang L, Gu FX, Chan JM, Wang AZ, Langer RS, Farokhzad OC. Nanoparticles in medicine: therapeutic applications and developments. Clin Pharmacol Ther. 2008;83(5):761-9. doi:10.1038/sj.clpt.6100400.

22. Dandekar PP, Jain R, Patil S, Dhumal R, Tiwari D, Sharma S, et al. Curcuminloaded hydrogel nanoparticles: application in anti-malarial therapy and toxicological evaluation. J Pharm Sci. 2010;99(12):4992-5010. doi:10.1002/jps.22191.

23. Sharma AS. U. S. Liposomes in drug delivery: progress and limitations. Int J Pharm. 1997;155(2):123-40. doi:10.1016/S0378-5173(97)00135-X.

24. Sou K, Inenaga S, Takeoka S, Tsuchida E. Loading of curcumin into macrophages using lipid-based nanoparticles. Int J Pharm. 2008;352(12):287-93. doi:10.1016/j.jppharm.2007.10.033.

25. Aiso S, Yamazaki K, Umeda Y, Asakura M, Kasai T, Takaya M, et al. Pulmonary toxicity of intratracheally instilled multiwall carbon nanotubes in male Fischer 344 rats. Ind Health. 2010;48(6):783-95.

26. Chen J, Dong X, Zhao J, Tang G. In vivo acute toxicity of titanium dioxide nanoparticles to mice after intraperitioneal injection. J Appl Toxicol. 2009;29(4):330-7. doi:10.1002/jat.1414.

27. Geys J, Nemmar A, Verbeken E, Smolders E, Ratoi M, Hoylaerts MF, et al. Acute toxicity and prothrombotic effects of quantum dots: impact of surface charge. Environ Health Perspect. 2008;116(12):1607-13. doi:10.1289/ ehp.11566.

28. Heng BC, Zhao X, Xiong S, Ng KW, Boey FY, Loo JS. Toxicity of zinc oxide ( $\mathrm{ZnO})$ nanoparticles on human bronchial epithelial cells (BEAS-2B) is accentuated by oxidative stress. Food Chem Toxicol. 2010;48(6):1762-6. doi:10.1016/j.fct.2010.04.023.

29. Liu S, Xu L, Zhang T, Ren G, Yang Z. Oxidative stress and apoptosis induced by nanosized titanium dioxide in PC12 cells. Toxicology. 2010;267(1-3):172-7. doi:10.1016/j.tox.2009.11.012.

30. Bouttefeux O, Beloqui A, Preat V. Delivery of peptides via the oral route: diabetes treatment by peptide-loaded nanoparticles. Curr Pharm Des. 2015;22(9):1161-76.

31. Naahidi S, Wang Y, Zhang M, Wang R, Jafari M, Yuan Y, et al. Evaluation of biocompatibility of the AC8 peptide and its potential use as a drug carrier. Mol Pharm. 2014;11(10):3409-20. doi:10.1021/mp5001185.

32. Patil KM, Naik RJ, Vij M, Yadav AK, Kumar VA, Ganguli M, et al. Second generation, arginine-rich ( $\left.\mathrm{R}-\mathrm{X}^{\prime}-\mathrm{R}\right)(4)$-type cell-penetrating alphaomega-alpha-peptides with constrained, chiral omega-amino acids ( $\left.X^{\prime}\right)$ for enhanced cargo delivery into cells. Bioorg Med Chem Lett. 2014;24(17):4198-202. doi:10.1016/j.bmcl.2014.07.040.

33. Qiu L, Hu Q, Cheng L, Li L, Tian C, Chen W, et al. CRGDyK modified pH responsive nanoparticles for specific intracellular delivery of doxorubicin. Acta Biomater. 2016;30:285-98. doi:10.1016/j.actbio.2015.11.037.

34. Gupta M, Bagaria A, Mishra A, Mathur P, Basu A, Ramakumar S, et al. Self-assembly of a dipeptide- containing conformationally restricted 
dehydrophenylalanine residue to form ordered nanotubes. Adv Mater. 2007;19(6):858-61. doi:10.1002/adma.200601774.

35. Mishra A, Panda JJ, Basu A, Chauhan VS. Nanovesicles based on selfassembly of conformationally constrained aromatic residue containing amphiphilic dipeptides. Langmuir ACS J Surf Colloids. 2008;24(9):4571-6. doi:10.1021/la7034533.

36. Panda JJ, Varshney A, Chauhan VS. Self-assembled nanoparticles based on modified cationic dipeptides and DNA: novel systems for gene delivery. J Nanobiotechnol. 2013;11:18. doi:10.1186/1477-3155-11-18.

37. Rao JP, Geckeler KE. Polymer nanoparticles: preparation techniques and size-control parameters. Prog Polym Sci. 2011;36(7):887-913. doi:10.1016/j.progpolymsci.2011.01.001.

38. Tamamis P, Adler-Abramovich L, Reches M, Marshall K, Sikorski P, Serpell L, et al. Self-assembly of phenylalanine oligopeptides: insights from experiments and simulations. Biophys J. 2009;96(12):5020-9. doi:10.1016/j. bpj.2009.03.026.

39. Zhang S. Emerging biological materials through molecular self-assembly. Biotechnol Adv. 2002;20(5-6):18.

40. Reches M, Gazit E. Casting metal nanowires within discrete self-assembled peptide nanotubes. Science. 2003;300(5619):625-7. doi:10.1126/ science. 1082387.

41. Panda JJ, Yandrapu S, Kadam RS, Chauhan VS, Kompella UB. Self-assembled phenylalanine-alpha, beta-dehydrophenylalanine nanotubes for sustained intravitreal delivery of a multi-targeted tyrosine kinase inhibitor. J Control Release. 2013;172(3):1151-60. doi:10.1016/j.jconrel.2013.09.016.

42. Zhao Y, Wang J, Deng L, Zhou P, Wang S, Wang Y, et al. Tuning the selfassembly of short peptides via sequence variations. Langmuir ACS J Surf Colloids. 2013;29(44):13457-64. doi:10.1021/la402441w.

43. Marchesan S, Vargiu AV, Styan KE. The Phe-Phe motif for peptide self-assembly in nanomedicine. Molecules. 2015;20(11):19775-88. doi:10.3390/molecules201119658.

44. De Jong WH, Borm PJ. Drug delivery and nanoparticles: applications and hazards. Int J Nanomed. 2008;3(2):133-49.

45. Guo L, Chen B, Liu R, Xia G, Wang Y, Li X, et al. Biocompatibility assessment of polyethylene glycol-poly L-lysine-poly lactic-co-glycolic acid nanoparticles in vitro and in vivo. J Nanosci Nanotechnol. 2015;15(5):3710-9.

46. Szymonowicz M, Rybak Z, Fraczek-Szczypta A, Paluch D, Rusak A, Nowicka $\mathrm{K}$, et al. Haemocompatibility and cytotoxic studies of non-metallic composite materials modified with magnetic nano and microparticles. Acta Bioeng Biomech. 2015;17(3):49-58.
47. Dhule SS, Penfornis P, Frazier T, Walker R, Feldman J, Tan G, et al. Curcuminloaded gamma-cyclodextrin liposomal nanoparticles as delivery vehicles for osteosarcoma. Nanomedicine. 2012;8(4):440-51. doi:10.1016/j. nano.2011.07.011.

48. Yallapu MM, Dobberpuhl MR, Maher DM, Jaggi M, Chauhan SC. Design of curcumin loaded cellulose nanoparticles for prostate cancer. Curr Drug Metab. 2012;13(1):120-8.

49. Hua S. Comparison of in vitro dialysis release methods of loperamideencapsulated liposomal gel for topical drug delivery. Int J Nanomed. 2014;9:735-44. doi:10.2147/IJN.S55805.

50. Mulik R, Mahadik K, Paradkar A. Development of curcuminoids loaded poly(butyl) cyanoacrylate nanoparticles: physicochemical characterization and stability study. Eur J Pharm Sci. 2009;37(3-4):395-404 doi:10.1016/j.ejps.2009.03.009

51. Nounou MM, El-Khordagui LK, Khalafallah NA, Khalil SA. In vitro release of hydrophilic and hydrophobic drugs from liposomal dispersions and gels. Acta Pharm. 2006;56(3):311-24.

52. Altunbas A, Lee SJ, Rajasekaran SA, Schneider JP, Pochan DJ. Encapsulation of curcumin in self-assembling peptide hydrogels as injectable drug delivery vehicles. Biomaterials. 2011;32(25):5906-14. doi:10.1016/j. biomaterials.2011.04.069.

53. Sommerfeld P, Sabel BA. U. S. long-term stability of PBCA nanoparticle suspensions. J Pharm. 1997;155(2):6.

54. Barik A, Priyadarsini Kl, Mohan H. Photophysical studies on binding of curcumin to bovine serum albumins. Photochem Photobiol. 2003;77(6):597-603.

55. Akhtar F, Rizvi MM, Kar SK. Oral delivery of curcumin bound to chitosan nanoparticles cured Plasmodium yoelii infected mice. Biotechnol Adv. 2012;30(1):310-20. doi:10.1016/j.biotechadv.2011.05.009.

56. Pan MH, Huang TM, Lin JK. Biotransformation of curcumin through reduction and glucuronidation in mice. Drug Metab Dispos. 1999;27(4):486-94.

57. Wang YJ, Pan MH, Cheng AL, Lin LI, Ho YS, Hsieh CY, et al. Stability of curcumin in buffer solutions and characterization of its degradation products. J Pharm Biomed Anal. 1997;15(12):1867-76.

58. Trager $W$, Jensen JB. Human malaria parasites in continuous culture. Science. 1976;193(4254):673-5.

\section{Submit your next manuscript to BioMed Central and we will help you at every step:}

- We accept pre-submission inquiries

- Our selector tool helps you to find the most relevant journal

- We provide round the clock customer support

- Convenient online submission

- Thorough peer review

- Inclusion in PubMed and all major indexing services

- Maximum visibility for your research

Submit your manuscript at www.biomedcentral.com/submit
() Biomed Central 